OPEN ACCESS

Edited by:

Duraisamy Saravanakumar, The University of the West Indies St

Augustine, Trinidad and Tobago

Reviewed by:

Mark A. Bernards,

Western University, Canada

Rakesh K. Upadhyay,

United States Department of Agriculture (USDA), United States

${ }^{*}$ Correspondence:

Martin Filion

martin.filion@canada.ca

Specialty section:

This article was submitted to

Crop Biology and Sustainability,

a section of the journal

Frontiers in Sustainable Food Systems

Received: 04 September 2020 Accepted: 23 November 2020

Published: 11 December 2020

Citation:

Novinscak A and Filion M (2020) Long

Term Comparison of Talc- and

Peat-Based Phytobeneficial

Pseudomonas fluorescens and

Pseudomonas synxantha

Bioformulations for Promoting Plant

Growth.

Front. Sustain. Food Syst. 4:602911.

doi: 10.3389/fsufs.2020.602911

\section{Long Term Comparison of Talc- and Peat-Based Phytobeneficial Pseudomonas fluorescens and Pseudomonas synxantha Bioformulations for Promoting Plant Growth}

\author{
Amy Novinscak ${ }^{1}$ and Martin Filion ${ }^{2 *}$ \\ ${ }^{1}$ Biology Department, Université de Moncton, Moncton, NB, Canada, ${ }^{2}$ Agriculture and Agri-Food Canada, \\ Saint-Jean-sur-Richelieu Research and Development Center, Saint-Jean-sur-Richelieu, QC, Canada
}

Use of plant growth promoting rhizobacteria (PGPR) is an important strategy in sustainable agriculture. Among PGPR, many Pseudomonas strains are of great interest due to their abilities to colonize and thrive in the rhizosphere, in addition to displaying mechanisms in plant growth promotion and biocontrol activities. However, as Pseudomonas strains are non-spore forming micro-organisms, their development into stable bioformulations for commercial applications can be difficult. This study examined over a long term period the effect of two different carriers, peat and talc, to prepare bioformulations using phytobeneficial Pseudomonas strains belonging to two taxonomical groups of interest: $P$. fluorescens and $P$. synxantha. Each strain has previously demonstrated plant growth promotion activity when inoculated in the rhizosphere. Each bioformulation was stored at ambient temperature and their viability was measured up to 180 days. In parallel, every 30 days (up to 180 days) each bioformulation was also applied in the rhizosphere of plantlets to validate their plant growth promotion activity, and their establishment in the rhizosphere was quantified by using strain-specific quantitative polymerase chain reaction assays. The viability of both Pseudomonas strains in the bioformulations was found to decrease after the first 15 days and remained relatively stable for up to 180 days. When applying the bioformulations to Buglossoides arvensis plantlets, the expected plant growth promotion was observed when using up to 180 day-old formulations of $P$. fluorescens and up to 120 day-old formulations of $P$. synxantha, with similar results for both carriers. Establishment of both Pseudomonas strains in the rhizosphere inoculated with the peat-based carrier bioformulations stored for up to 180 days was found to be stable. While a lower establishment of $P$. fluorecens in the rhizosphere was observed when talc-based bioformulations were stored for 90 days or more, rhizosphere colonization by $P$. synxantha talc-based bioformulations remained stable for up to 180 days. In conclusion, both peat and talc appear to be suitable carriers for Pseudomonas bioformulations, 
however strain-specific variability exists and therefore the viability of each Pseudomonas strain and its capacity to maintain its plant growth promotion activity should be validated in different substrates before determining which formulation to use.

Keywords: bioformulation, Pseudomonas, peat, talc, carrier, plant-growth-promotion

\section{INTRODUCTION}

The world population is increasing at an alarming rate and is set to reach 9 billion by the year 2050, while the land available for agriculture has been decreasing due to industrialization (Aamir et al., 2020). Food production has increased through advances in agriculture such as the use of chemical pesticides and fertilizers, as well as breeding efforts to develop plant cultivars that are more productive and more stress tolerant (Aamir et al., 2020). However, plant productivity is still impacted by different environmental stresses such as drought, salinity, and limited nutrient availability (Basu et al., 2017; Aamir et al., 2020). Additionally, global climate change will also increasingly affect agriculture worldwide through increased surface temperature and reduced soil moisture (Basu et al., 2017). Conventional agriculture relies heavily on chemical pesticides and fertilizers to control pests and improve plant growth. The use of chemical pesticides varies among crops but data has shown that up to 93\% of row crops such as corn, soybean, and cotton are treated with some kind of pesticide (Pimentel, 1993). Chemical pesticides have proven successful at preventing some crop diseases and enhancing crop productivity, however their role in damaging agro-ecosystems is now better understood (Mishra and Arora, 2016). Studies show that most chemical pesticides used in conventional agriculture can have detrimental effects on human health (Moses et al., 1993; Reigart and Roberts, 2013). In addition to their negative effects on human health, chemical pesticides can also negatively affect aquatic systems, the wildlife and the richness of soil microorganisms (Dorigo et al., 2009). The use of chemical fertilizers has also been beneficial to achieve greater crop productivity, however long-term experiments on the effects of fertilizers on soil fertility have shown that continual use can decrease soil quality (Kumar and Yadav, 2001; Yang, 2006).

Sustainable agriculture has been increasing in interest as a method to produce food to feed the growing population using environmentally friendly approaches. One attractive and economical approach is the use of plant growth promoting rhizobacteria (PGPR) to improve crop productivity and achieve higher yields (Antoun and Kloepper, 2001). PGPR are a functional group of bacteria that include different genera such Rhizobium, Bradyrhizobium, Mesorhizobium, Azotobacter, Enterobacter, Xanthomonas, Bacillus, and Pseudomonas (Bashan, 1998; Bishnoi, 2015; Zayed, 2016; Berninger et al., 2018; Aamir et al., 2020). PGPR make up from 2 to $5 \%$ of all bacteria found in the rhizosphere (the soil area surrounding plant roots) (Antoun and Kloepper, 2001) and specific PGPR strains can be used alone or in combination to achieve different ecological functions leading to improved plant yields. Their use coupled with other crop management practices can lead to a reduction in the amount of chemicals used in the field without reducing crop yields. Among PGPR of interest, Bacillus and Pseudomonas are the most widely reported genera (Podile and Kishore, 2007). PGPR, and especially Bacillus and Pseudomonas, are of interest due to their ease of growth in the laboratory and their abilities to increase plant yields and/or improve plant health through various direct and indirect mechanisms of action. Direct methods include phosphate solubilization, nitrogen fixation, phytohormone production, iron acquisition, and the stimulation of plant defenses. Indirect methods include antibiosis, production of protective enzymes, induced systemic resistance, and the production of ACC-deaminase, which reduces the amounts of ethylene in the plant (Podile and Kishore, 2007; Martínez-Viveros et al., 2010; Zayed, 2016; Berninger et al., 2018; Bhattacharyya et al., 2020). Other beneficial traits of PGPR include their ability to efficiently colonize the root surface or the soil surrounding the roots, survive, compete and multiply in the soil (Bhattacharyya et al., 2017). PGPR that facilitate nutrient acquisition are known as biofertilizers, while PGPR that produce plant hormones are known as phytostimulators, and those that suppress diseases are known as biocontrol agents (Martínez-Viveros et al., 2010; Bishnoi, 2015). Some PGPR strains belong to more than one category. Biofertilizers, phytostimulators and biocontrol agents are considered key components of sustainable agriculture and are known to improve crop productivity in an ecofriendly manner. The biofertilizer market (comprising biofertilizers, phytostimulators, and biocontrol agents) is estimated to be worth 1.66 billion USD in 2022 and displayed an annual growth rate of $13.2 \%$ between 2015 and 2022, representing $\sim 5 \%$ of the overall chemical-based fertilizers market (Macik et al., 2020).

A promising microbial inoculant must first be developed into a bioformulation to be used as a commercial product. A bioformulation is developed by combining a biologically active ingredient (living microbe or spore) with inert substances, known as carriers, to obtain a formulated product (Aamir et al., 2020). Common carriers include peat, talc, vermiculite, and diatomaceous earth (Bashan, 1998; Zayed, 2016). The carrier provides a temporary protective surface to the microorganism and must demonstrate the ability to support the growth of the target organism and maintain desired populations over an acceptable period of time (Macik et al., 2020). Carriers must have high water holding capacity, be well-buffered, environmentally safe, easy to use, and cost-effective (Bashan, 1998; Zayed, 2016; Bhattacharyya et al., 2020). Bioformulations are often divided into categories based on the composition of the carrier. These can include peat, liquid, granules, and freeze-dried powders (Abadias et al., 2005; Guijarro et al., 2007; Bhattacharyya et al., 2020). Among these, peat is one of the most common 
carriers used worldwide (Bhattacharyya et al., 2020). Peat has a high water-holding capacity, high organic matter content, and is easily available (Bhattacharyya et al., 2020). Sticking agents are often added to peat-based biofertilizers to evenly distribute and stabilize the microorganism and can include carboxymethylcellulose, arabic gum, and polyalcohol derivatives (Bhattacharyya et al., 2020). Liquid formulations are aqueous suspensions made in oil, water, or a combination of both (Schisler et al., 2004). They are also a popular type of bioformulation; however, they can have reduced survival and propagation rates when compared to solid carriers (Berninger et al., 2018).

Developing a successful bioformulation can be a difficult process, as extensive trials must be conducted before the product can be marketed. Many bacteria are tested in pot assays under strict controlled settings, and their subsequent testing under field conditions can be inconsistent with pot studies or even unsuccessful (Lugtenberg and Kamilova, 2009; Backer et al., 2018). Many uncontrollable factors are found in the field such as variations between different field sites, year to year environmental variation, and even from growing different crops in the same field (Raaijmakers et al., 2009; Compant et al., 2010; Bishnoi, 2015). Soil is notoriously heterogeneous and introduced microorganisms can be unable to find an empty niche (Bishnoi, 2015). It is of utmost importance that the inoculated microorganism is able to compete with indigenous microorganisms and establish itself and survive in the rhizosphere. Many studies have shown that following a PGPR application, a sharp decline in its population is observed after a few weeks (Verma et al., 2013; Bishnoi, 2015; Corrêa et al., 2015; Novinscak and Filion, 2019). Additionally, the microorganism used to develop the bioformulation should be compatible with mass multiplication and not display any toxicological effects to the plants or other beneficial microorganisms (Bishnoi, 2015). Another difficulty encountered when developing bacterial bioformulations is the use of Gram-negative strains because they do not produce spores (Berninger et al., 2018), which are often used for Gram-positive bacterial formulations. Gram-negative bacteria have however been found to be important PGPR, but due to their inability to produce spores, have a shorter shelflife and are easily killed during desiccation of the formulation (Ramakrishna et al., 2019). One method used to counter the short shelf-life of Gram-negative bacterial formulations is to increase the number of microbes in the inoculant (Bashan et al., 2014; Tabassum et al., 2017). Even with a declining population over time, sufficient cells often remain alive to achieve a positive effect on the plants when applying the bioformulation in the field (Bashan et al., 2014).

Pseudomonas strains are some of the most recognized strains of PGPR found in the rhizosphere (Podile and Kishore, 2007), however, they have not been widely commercialized in large part due to the rapid loss of viability of the available bioformulations (Corrêa et al., 2015). Pseudomonas strains represent only 6\% of the commercial biocontrol and biofertilizer products available for plants as compared to Bacillus strains which represent 15\% and Trichoderma fungal species, which lead the way with $43 \%$ (Bettiol et al., 2012). Pseudomonas strains are also found to be highly susceptible to environmental stress factors, such as drought and high temperatures (Paulitz and Bélanger, 2001). Greater commercial use of Pseudomonas strains in crops will depend on the formulation of products with greater shelf life and the demonstration that the products are viable and effective when applied to plants. High moisture levels, favorable $\mathrm{pH}$ values and low temperature favors the survival of Pseudomonas strains in carrier materials (Corrêa et al., 2015). Our research group has thoroughly examined the plant growth promoting effects of two strains of Pseudomonas species, Pseudomonas fluorescens LBUM677 and Pseudomonas synxantha LBUM223. Previous studies conducted with LBUM677 have shown that in addition to plant growth promotion properties, the bacterium is able to increase seed oil content in various oilseed plants, including in corn gromwell (Buglossoides arvensis), a plant of high nutraceutical interest, under various field settings (Novinscak and Filion, 2018, 2019; Jiménez et al., 2020). LBUM223 has demonstrated plant growth promotion properties and has been successful in reducing the symptoms of the bacterial pathogen Streptomyces scabies on potato plants in controlled and field settings (St-Onge et al., 2010, 2011; Arseneault et al., 2015). To reach the goal of eventually commercializing these strains, we wished to evaluate the survival and viability of these strains over a long period of time when produced in bioformulations. The present study examined their viability in two solid carriers, peat and talc, their capacity to colonize the rhizosphere when formulated in these carriers and stored for up to 180 days and finally their ability to conserve their plant growth promotion activity. Interestingly, many Pseudomonas strains isolated to date which display strong PGPR abilities belong to the P. fluorescens and $P$. synxntha species. We therefore anticipate that the findings obtained in this study using LBUM677 and LBUM223 will, at least in part, be applicable to other P. fluorescens and P. synxantha strains of interest.

\section{MATERIALS AND METHODS}

\section{Bacterial Preparation}

$P$. fluorescens LBUM677 and P. synxantha LBUM223 were originally isolated from the rhizosphere of strawberry plants cultivated in Bouctouche, NB, Canada. Three replicates of precultures of each bacterium were prepared by inoculating each bacterium in King's B broth (King et al., 1954) and incubating at $25^{\circ} \mathrm{C}$ with agitation at $150 \mathrm{rpm}$ for $24 \mathrm{~h}$. Each pre-culture was used to inoculate larger volumes of King's B broth (used for inoculum preparation) and incubated at $25^{\circ} \mathrm{C}$ with agitation at $150 \mathrm{rpm}$ for $48 \mathrm{~h}$. The bacterial concentrations were determined to range from $2.4 \times 10^{11}$ to $3.7 \times 10^{11} \mathrm{cfu} \mathrm{mL}^{-1}$ for LBUM677 and $8.8 \times 10^{11}$ to $1.0 \times 10^{12} \mathrm{cfu} \mathrm{mL}^{-1}$ for LBUM223 based on $\mathrm{OD}_{600 \mathrm{~nm}}$ measurements and previously determined growth curves (Novinscak and Filion, 2018).

\section{Inoculum Preparation}

Talc (Fisher Scientific, Ottawa, Canada) and peat-based (Green Island peat moss, Isle-Verte, Canada) formulations of each Pseudomonas strain were prepared by following the method of Vidhyasekaran and Muthamilan (1995). One large batch of each carrier was prepared by mixing eight kilograms of each carrier 
with $80 \mathrm{~g}$ of carboxymethylcellulose (Sigma Aldrich, Oakville, Canada) and the $\mathrm{pH}$ was adjusted to 7 using calcium carbonate (Sigma Aldrich, Oakville, Canada). After adjusting the $\mathrm{pH}$, eight aliquots of one $\mathrm{kg}$ of each substrate were prepared and were sterilized by autoclaving the carriers for $60 \mathrm{~min}$ at $121^{\circ} \mathrm{C}$ twice, on separate days.

Triplicates of each bacterium were inoculated in each carrier by aseptically adding $400 \mathrm{ml}$ of bacterial suspension (see bacterial preparation) to $1 \mathrm{~kg}$ of carrier and mixing well. Duplicate negative controls were also prepared by aseptically adding $400 \mathrm{ml}$ of uninoculated King's B broth to $1 \mathrm{~kg}$ of carrier and mixing well. Each bioformulation (eight for each carrier type; three inoculated with LBUM223, three inoculated with LBUM677 and two negative controls, inoculated with King's B broth) were air dried overnight and were then stored in the dark in polythene bags at room temperature $\left(\sim 25^{\circ} \mathrm{C}\right)$.

\section{Evaluation of the Shelf Life of the Talc and Peat Formulations}

The viability of the bioformulations was tested after their storage for specific intervals of time (stored for 15 days, stored for 30 days, stored for 45 days, stored for 60 days, stored for 90 days, stored for 120 days, stored for 150 days, and stored for 180 days). After each storage time, one gram of each of the bioformulations was added to nine $\mathrm{ml}$ of sterile water, mixed, and six serial dilutions (from $10^{-2}$ to $10^{-7}$ ) were prepared. One hundred $\mu l$ of each dilution was plated in triplicate on Petri containing King's $\mathrm{B}$ medium. The Petri were incubated at $25^{\circ} \mathrm{C}$ for $48 \mathrm{~h}$ before determining the number of colony-forming units on each plate.

\section{Growth Promotion of Corn Gromwell Using Talc and Peat Formulations}

After the bioformulations were stored for 30 days, 60 days, 90 days, 120 days, and 180 days, the plant growth promotion effect of the bioformulations was also measured by mixing one gram of each bioformulation to $50 \mathrm{~g}$ of non-sterile soil and adding three Buglossoides arvensis seeds to each pot (to account for low germination rates). After germination, only one plant per pot was kept. The non-sterile soil used was obtained from a field at the Senator Hervé J. Michaud Agriculture and AgriFood Canada Research Farm (Bouctouche, NB, Canada) and was characterized as a Gleyed Podzolic Gray Luvisol (GLPZ.GL), per the Canadian Soil Classification System with 62\% sand, 25\% silt, $13 \%$ of clay, $2.6 \%$ organic matter and a $\mathrm{pH}$ of 5.2 (National Research Council of Canada, 1987). A total of 320 experimental units was used (eight bioformulations for each carrier type; two carrier types; five time-points; four replicates). The $B$. arvensis plantlets were grown for 60 days at $20^{\circ} \mathrm{C}$ and a $12 \mathrm{~h}$ photoperiod. At 60 days, the rhizosphere soil was collected from each plant (destructive sampling), flash frozen in liquid nitrogen and stored at $-80^{\circ} \mathrm{C}$ and the plant's total fresh weight (root and shoot weight) was measured.

\section{Rhizosphere Competence of $P$. synxantha LBUM223 and $P$. fluorescens LBUM677}

As mentioned previously, on each sampling date, rhizosphere soil was harvested from each plant, flash frozen in liquid nitrogen and stored at $-80^{\circ} \mathrm{C}$. A total of 320 rhizosphere samples were collected by the end of the experiment. The rhizosphere soil was subsequently lyophilized using a lyophilizer (Thermo Fisher Scientific, Mississauga, Canada). DNA was extracted from $0.5 \mathrm{~g}$ of rhizosphere soil using the method described in Griffiths et al. (2008). Following DNA extraction, all samples were diluted 1:10 before being used in qPCR. qPCR standards for LBUM223 and LBUM677 were created as previously described (deCoste et al., 2011) using a diluted cloned PCR fragment obtained from each bacterium using specific PCR primers. PCR primers and a TaqMan probe targeting a specific DNA sequence in LBUM223 were developed previously in Arseneault et al. (2016) (223phzCfor: 5' - ATA GAT GGA ATG CCG GTC ATG-3'; 223phzCrev: 5'- GCC CTC CTC CCT CTT TTG TTT-3' and 223phzCprobe: 5' - FAM-CGA CAA ACT CCA GTC AAMGBNFQ- $3^{\prime}$ ) while PCR primers and a TaqMan probe targeting a specific DNA sequence in LBUM677 were developed previously in Novinscak and Filion (2019) (BOX18F 5'- GCC TGC ATC GCG GTC TT-3'; BOX18R 5' - CCC AAT CGG GTG ATC ATT G-3' and BOX18probe $5^{\prime}$ - FAM-ATC ATA GAC TCG GAA TTG T-MGBNFQ-3'). The qPCR reactions were performed in $20 \mu \mathrm{l}$ and consisted of: $10 \mu \mathrm{l}$ of 10X iTaq Mix (Bio-Rad Laboratories, Mississauga, Canada), $0.8 \mu \mathrm{l}$ of $5 \mu \mathrm{M}$ of each probe, $0.8 \mu \mathrm{l}$ of $5 \mu \mathrm{M}$ of each primer, $3.0 \mu \mathrm{l}$ of DNA and $4.6 \mu \mathrm{l}$ of DEPCtreated $\mathrm{H}_{2} \mathrm{O}$. The amplification protocol was performed in a 7500 Real Time PCR machine (Applied Biosystems, Mississauga, Canada) and consisted of $95^{\circ} \mathrm{C}$ for $3 \mathrm{~min}$ followed by 50 cycles of denaturation at $95^{\circ} \mathrm{C}$ for $15 \mathrm{~s}$ and annealing/extension at $60^{\circ} \mathrm{C}$ for $60 \mathrm{~s}$. Data collection was performed at the end of the annealing/extension step.

\section{Statistical Analyses}

The data from the bioformulation viability assay was rank transformed before statistical analysis. Data was separated by bacterium and a two factor ANOVA (sampling date and carrier type as factors) was used to examine the effects on the bacterial populations. For the plant growth promotion assays, each timepoint was examined separately. Data were rank transformed when necessary. A two-factor ANOVA was used to measure the effect of the carrier type and the bacterial inoculation (LBUM677, LBUM223 or control) on plant weight. Finally, for the rhizosphere competency assay, the results for each bacterium were analyzed separately. A two-factor ANOVA examining the effect of the sampling date and the carrier type was performed. $P$-values below 0.05 were considered significant. SAS software version 9.2 (SAS Institute Inc, NC, USA) was used for all statistical analyses.

\section{RESULTS}

\section{Evaluation of the Shelf-LIFE of Talc and Peat Bioformulations of $P$. fluorescens LBUM677 and $P$. synxantha LBUM223}

LBUM677's survival rate was higher in the peat carrier than the talc carrier (Table 1), while no difference was observed between the two carriers for LBUM223 (Table 1). For both bacteria, the population levels decreased almost two log values $\left(\mathrm{cfu} \mathrm{g}^{-1}\right)$ from 
TABLE 1 | Shelf-life of talc and peat bioformulations of $P$. fluorescens LBUM677 and $P$. synxantha LBUM223 determined by plating dilutions of inoculum at each time point.

\begin{tabular}{|c|c|c|c|c|c|c|c|c|}
\hline \multirow[b]{2}{*}{ Carrier formulation and treatment } & \multicolumn{8}{|c|}{ Population ( $10^{7} \mathrm{cfu}$ per $\left.\mathrm{g}\right)$ at various days of storage } \\
\hline & 15 & 30 & 45 & 60 & 90 & 120 & 150 & 180 \\
\hline Peat + LBUM677 & $634.0 \mathrm{ab}^{\#^{*}}$ & $306.0 \mathrm{ab}$ & $293.0 \mathrm{ab}$ & $205.0 \mathrm{ab}$ & $392.0 \mathrm{abc}$ & 11.0 cdef & 3.7 ef & $3.0 \mathrm{f}$ \\
\hline Talc + LBUM677 & $455.0 \mathrm{ab}$ & $45.1 \mathrm{bcd}$ & 12.5 cdef & 25.2 bcde & 8.4 def & 6.0 ef & 8.2 def & 23.0 bcdef \\
\hline Peat + LBUM223 & $1190.0 \mathrm{ab}$ & $268.0 \mathrm{ab}$ & $294.0 \mathrm{ab}$ & $197.0 \mathrm{ab}$ & $48.2 \mathrm{bcd}$ & 7.3 cdef & 4.9 ef & 5.2 def \\
\hline Talc + LBUM223 & $476.0 \mathrm{ab}$ & $105.0 \mathrm{bc}$ & 5.1 cdef & 27.1 bcde & $3.2 f$ & 6.1 cdef & 3.4 ef & 4.2 ef \\
\hline
\end{tabular}

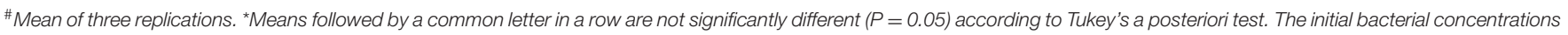
inoculated in the substrates were $2.81 \times 10^{11}$ cfu per $g$ for LBUM677 and $9.60 \times 10^{11}$ cfu per $g$ for LBUM223.

the initial inoculation of the carriers to the first sampling date, 15 days later (Table 1). A difference between the population levels of LBUM677 between peat and talc was first observed at 45 days and again at 90 days, however this difference between carriers was not maintained over time. Similarly, a difference between the LBUM223 population levels of both carriers was also observed at 45 and 90 days, however, as with LBUM677, the difference was not maintained. Over the course of the experiment, the population levels decreased by four log values from $\sim 1 \times 10^{11}$ to $1 \times 10^{7} \mathrm{cfu} \mathrm{g}^{-1}$ for both bacteria in both substrates.

\section{Growth Promotion of Corn Gromwell by $P$. fluorescens LBUM677 and $P$. synxantha LBUM223}

The effect of the bacterial treatment was found to significantly influence the plant weight at all time-points measured when compared to the controls having received the carriers only without the bacteria (Figure 1). However, a significant effect of the carrier was only observed sporadically when the carriers reached 60, 90, and 180 days of storage (Figure 1). The plant growth promotion effect was observed for both bacteria at most time points, however, a difference between the effects of the two bacteria was initially observed when the bioformulations were stored for 90 days and this trend remained to the end of the experiment. The LBUM677 talc bioformulation was found to increase the plant weight from 12 to $380 \%$ (as compared to controls) at all time-point analyzed. The LBUM677 peat bioformulation was found to increase the plant weight from 37 to $364 \%$ at all time-points except for the 30 days bioformulation, which actually decreased the plant weight by $8 \%$ as compared to the control. The LBUM223 talc bioformulation was found to increase the plant weight by 93 to $130 \%$, but only when the bioformulation was between 60 and 120 days of age. This was also observed in the LBUM223 peat bioformulation, where the plant weight was increased by 67 to $139 \%$ during the same timepoints. Both LBUM223 bioformulations had a negative effect on the plant weight at 30 days and 180 days (Figure 1).

\section{Rhizosphere Competence of $P$. fluorescens LBUM677 and $P$. synxantha LBUM223}

When examining the rhizosphere competency of both bacteria evaluated using specific qPCR assays, LBUM677 was found to establish itself with higher population levels in the rhizosphere of corn gromwell than LBUM223 (Table 2). Additionally, LBUM677 populations were found to be higher when peat was used as a carrier than talc. When using the peat carrier, the LBUM677 populations were found to be stable throughout the experiment, however there was a significant decrease in the LBUM677 populations when talc was instead used. For LBUM223, no difference was observed in the rhizosphere competence between talc or peat carriers. The LBUM223 populations were found to be relatively stable throughout the entire experiment with significantly lower population levels observed at 120 days, however, this difference was no longer observed at 180 days.

\section{DISCUSSION}

The overall results of this study show that bioformulations stable up to 180 days at room temperature were successfully developed for two distinct Pseudomonas species. Both P. fluorescens and $P$. synxantha remained viable, could colonize the rhizosphere, and achieve plant growth promotion. When trying to determine if peat or talc would be a better carrier in general for Pseudomonas strains, our results indicated that both carriers yielded similar results at most time-points for both bacteria and demonstrated a shelf-life up to 180 days. Cell viability at 180 days in peat was similar for LBUM677 and LBUM223 $\left(3 \times 10^{7}\right.$ and $5 \times 10^{7} \mathrm{cfu}$ $\mathrm{g}^{-1}$, respectively), while results for talc were better for LBUM677 than LBUM223 $\left(2 \times 10^{8}\right.$ and $4 \times 10^{7} \mathrm{cfu} \mathrm{g}^{-1}$, respectively). These results differ from those obtained comparing talc and peat as carriers for Pseudomonas fluorescens strains Pf1 and Pf2 showing that talc formulations were viable after 180 days of storage while peat formulations were only effective for up to 120 days of storage (Vidhyasekaran et al., 1997). The survivability of P. fluorescens strains Pf1 and Pf2 in six different carriers was tested and talc was also found to be the best carrier and maintained the highest populations of $P$. fluorescens at the end of 6 months of storage at $1.8 \times 10^{9} \mathrm{cfu}^{-1}$ carrier (Gade et al., 2014). However, other results obtained using peat-based carriers, similar to the ones obtained in our study, showed that $P$. fluorescens Pf1, Pf2, and Pf27 remained viable for up to 8 months at a population of $7 \times 10^{6} \mathrm{cfu}^{-1}$ (Vidhyasekaran and Muthamilan, 1995), and P. chlororaphis PA23 successfully maintained a shelf life of more than 6 months in a peat carrier (Nakkeeran et al., 2004). The survival of P. fluorescens PfALR2 



FIGURE 1 | Total plant fresh weight (in grams) of corn gromwell inoculated with peat or talc bioformulations of LBUM677, LBUM223, or control that were stored for (A) 30 days, (B) 60 days, (C) 90 days, (D) 120 days, and (E) 180 days. All plants were harvested at the same age and destructively sampled at the same development stage (after 60 days of growth). Black bars represent bioformulations prepared with peat while gray bars represent bioformulations prepared with talc. Different letters indicate statistically significant differences between treatments.

in peat, talc, and lignite was measured up to 60 days and peat was found to be a better carrier for this bacterium than talc and lignite (populations of $4.4 \times 10^{7} \mathrm{cfu} \mathrm{g}^{-1}$ for peat as compared to $2.9 \times 10^{7} \mathrm{cfu}^{-1}$ for talc) (Rabindran and Vidhyasekaran, 1996). Another study also tested three different carrier materials (cocopeat, talc, and farmyard manure) for their ability to support the growth of two Pseudomonas sp. isolates (An-2-nali and Pn2-kho) (Verma et al., 2013). Cocopeat had the longest shelf-life of up to 7 months with a population of $1 \times 10^{4} \mathrm{cfu} \mathrm{g}^{-1}$ (An2-nali strain), while the shortest shelf-life was observed in the 
TABLE 2 | Rhizosphere competence of LBUM677 and LBUM223 bioformulations as determined by measuring the populations of each bacterium in rhizosphere soil using real-time PCR when the bioformulations reached different ages.

\begin{tabular}{|c|c|c|c|c|c|}
\hline \multicolumn{6}{|c|}{$\begin{array}{l}\left.\text { Population ( } 10^{7} \text { cfu per } \mathrm{g}\right) \text { of bacteria in the rhizosphere soil detected using real-time PCR at various bioformulation } \\
\text { ages (days) }\end{array}$} \\
\hline Carrier formulation and treatment & 30 & 60 & 90 & 120 & 180 \\
\hline Peat + LBUM677 & $29.40 \mathrm{a}^{\#^{*}}$ & $7.94 \mathrm{ab}$ & $16.00 \mathrm{a}$ & $3.40 \mathrm{ab}$ & $12.00 \mathrm{ab}$ \\
\hline Talc + LBUM677 & $1.53 \mathrm{abc}$ & 7.04 bc & $0.71 \mathrm{c}$ & $0.23 c$ & $2.23 \mathrm{c}$ \\
\hline Peat + LBUM223 & $0.04 \mathrm{a}$ & $0.12 \mathrm{a}$ & $0.23 a b$ & $0.01 \mathrm{~b}$ & $0.11 \mathrm{a}$ \\
\hline Talc + LBUM223 & $0.16 \mathrm{a}$ & $0.34 a$ & $0.08 a b$ & $0.01 \mathrm{~b}$ & $0.31 \mathrm{a}$ \\
\hline
\end{tabular}

\# Mean of twelve replications (3 substrates $\times 4$ plants). *Means followed by the same letter in a row are not significantly different (P $=0.05)$ according to Tukey's a posteriori test.

farmyard manure. Their results indicated that a smaller particle size of the carrier lead to an increased shelf-life (Verma et al., 2013).

The initial quantity of bacteria used to prepare the inoculum in this study was higher than what has been previously reported in the literature, where concentrations ranged from $1 \times 10^{8} \mathrm{cfu}$ $\mathrm{ml}^{-1}$ up to $2.5 \times 10^{9} \mathrm{cfu} \mathrm{ml}^{-1}$ (Rabindran and Vidhyasekaran, 1996; Shaharoona et al., 2007; Jorjani et al., 2011; Jambhulkar and Sharma, 2013; Verma et al., 2013; Gade et al., 2014; Dubey and Kumar, 2018). The higher quantity determined in our study was achieved using a starter culture of each bacterium to inoculate the larger volumes required for the inoculations of the carriers. Studies have expressed that one of the ways to circumvent the decline in bacterial populations in a carrier is to use higher initial levels of the bacteria, however this approach might not always be economically efficient (Berninger et al., 2018). Even using higher initial amounts of cells, the population levels of both bacteria in our study decreased by four log-values from $\sim 1 \times 10^{11}$ to $1 \times$ $10^{7} \mathrm{cfu} \mathrm{g}^{-1}$ carrier. A previous study found a rapid decrease in population levels of two $P$. chlororaphis strains (63-28 and TX-1) from $5 \times 10^{9}$ bacterial $\mathrm{cfu} \mathrm{m}^{-1}$ to $1 \times 10^{8}-1 \times 10^{5}$ bacterial cfu $\mathrm{ml}^{-1}$ in peat and talc in as little as $15 \mathrm{~h}$ after inoculation (Corrêa et al., 2015). However, in that study, the $\mathrm{pH}$ of talc or peat was not adjusted to a neutral value of 7 (it was maintained at 9 for talc and 3 for peat), which could explain the rapid decrease in bacterial populations observed. As increasing initial bacterial populations in carriers does not always lead to longer survival, efforts should be made to optimize storage conditions for longterm bacterial survival, including determining optimal storage temperatures and water content (Berninger et al., 2018).

In addition to a long shelf-life, bioformulations must also maintain their effectiveness to colonize their target plants. Interestingly, when examining this factor, LBUM677 was able to maintain its positive effect of promoting plant growth at almost all time-points except the initial time-point of 30 days (Table 2). The effects of LBUM223 on plant growth promotion were not as significant as LBUM677 (as compared to control) and even displayed a negative effect on plant weight at 30 days and 180 days as compared to controls. Differences in the activity of the two strains under study is most likely due to differences in their biochemical and/or genetic characteristics. This has previously been observed in bentonite and talc formulations of Pseudomonas sp. and CKK-3 on cotton seedlings. Strain was found to be more effective than strain CKK-3, likely due to differences in characteristics of this isolate (Sobhan et al., 2011). Other studies have shown the positive effects of Pseudomonas sp. bioformulations on various plant species. Specifically, four talc formulations of Pseudomonas sp. isolates CHAO, EP1, KKM, and VPT4 were successful in improving millable sugarcane height under field conditions (Viswanathan and Samiyappan, 2008). Wheat yield was improved by $15-25 \%$ over controls when using Pseudomonas moraviensis and Bacillus cereus bioformulations (Hassan and Bano, 2015). Seed treatment of wheat with $P$. fluorescens RRb-11 in talc led to significantly increased plant growth parameters and even increased seed germination by $94 \%$ over controls (Jambhulkar and Sharma, 2013). Pseudomonas fluorescens bioformulations showed the highest effectiveness of 8 different bioformulations on the fresh weight of sugar beets (Jorjani et al., 2011). Pseudomonas putida PT inoculated on maize seeds significantly enhanced the fresh and dry weights of the plants at harvest time (Khashei et al., 2020). Finally, chickpea seeds treated with talc or peat formulations of Pseudomonas spp. effectively controlled chickpea wilt disease in two field trials and increased the chickpea yield (Vidhyasekaran and Muthamilan, 1995).

In addition to the effect of the biofertilizers on the plant's weight, we also examined the persistence of each bacteria in the rhizosphere of corn gromwell. The rhizosphere competency of a bacterial strain is important for its ability to be a successful PGPR (Compant et al., 2019; Rilling et al., 2019). Also, before a new PGPR strain is developed into a bioformulation and commercialized for field applications, it is essential for regulatory considerations to develop reliable bioassays capable of detecting and quantifying the strain of interest among the complex soil microbiome (Mathre et al., 1999). In our study, specific qPCR bioassays were used for both strains under study, which successfully allowed to detect and quantify both strains in rhizosphere soil. Surprisingly, only few studies to date examined the population levels of inoculated bacteria in the rhizosphere and instead relied on increases in plant biomass and other plant parameters to confirm successful PGPR activity (Rilling et al., 2019).

Another important consideration when testing a bioformulation's viability and establishment in the rhizosphere is the capacity to translate results obtained in controlled conditions, often in pots, to the field. Various Pseudomonas strains in peat 
carrier have been tested in pot and field trials. Most strains displayed plant yield increases as compared to controls, however the results for a given strain were not consistent between pot and field trials (Shaharoona et al., 2007; Tabassum et al., 2017). Weather conditions, soils, plants, and the indigenous microorganisms in fields are all variable, leading to no specific rules for optimizing the inoculation of biofertilizers in soil (Khare and Arora, 2015). The success of the biofertilizer in field soil is dependent on its survival and ability to function in this heterogeneous environment. Abiotic factors (e.g., soil texture, $\mathrm{pH}$, temperature and moisture levels) in the field exert their effects on inoculant population dynamics by imposing various stresses on the microbial cells (Evans et al., 1993; Khare and Arora, 2015). In our study, non-sterile field soil was used when performing pot studies, to help account for these abiotic factors found in this type of soil. This approach has previously allowed us to minimize the differences often observed between pot and field results with various PGPR and plant systems (St-Onge et al., 2011; Novinscak and Filion, 2018; Jiménez et al., 2020). The next step to validate the results obtained in this study will be to perform similar inoculation experiments under field conditions and track the PGPR strains in soil using the qPCR bioassays already available for LBUM223 and LBUM677. In parallel, the efficacy of the same carriers and inoculation approach will be validated for other Pseudomonas strains in development in our laboratory.

In conclusion, despite the apparent difficulty to develop stable bioformulations for non-sporulating plant beneficial Pseudomonas PGPR, significant progress is being made. Peat and talc-based carriers show great potential to assure viability of Pseudomonas strains at room temperature for many months

\section{REFERENCES}

Aamir, M., Rai, K. K., Zehra, A., Dubey, M. K., Kumar, S., Shukla, V., et al. (2020). "Microbial bioformulation-based plant biostimulants: a plausible approach toward next generation of sustainable agriculture," in Microbial Endophytes Functional Biology and Applications, eds A. Kumar and E. K. Radhakrishnan (Oxford: Elsevier), 195-225. doi: 10.1016/B978-0-12-819654-0.00008-9

Abadias, M., Teixidó, N., Usall, J., Solsona, C., and Viñas, I. (2005). Survival of the postharvest biocontrol yeast Candida sake CPA- 1 after dehydration by spraydrying. Biocontrol Sci. Technol. 15, 835-846. doi: 10.1080/09583150500187041

Antoun, H., and Kloepper, J. (2001). "Plant growth promoting Rhizobacteria (PGPR)," in Encyclopedia of Genetics, eds S. Brenner and J. H. Miller (New York, NY: Elsevier), 1477-1480. doi: 10.1006/rwgn.2001.1636

Arseneault, T., Goyer, C., and Filion, M. (2015). Pseudomonas fluorescens LBUM223 increases potato yield and reduces common scab symptoms in the field. Phytopathology 105, 1311-1317. doi: 10.1094/PHYTO-12-14-0358-R

Arseneault, T., Goyer, C., and Filion, M. (2016). Biocontrol of potato common scab is associated with high Pseudomonas fluorescens LBUM223 populations and phenazine-1-carboxylic acid biosynthetic transcripts accumulation in the potato geocaulosphere. Phytopathology 106, 963-970. doi: 10.1094/PHYTO-01-16-0019-R

Backer, R., Rokem, J. S., Ilangumaran, G., Lamont, J., Praslickova, D., Ricci, E., et al. (2018). Plant growth-promoting rhizobacteria: context, mechanisms of action, and roadmap to commercialization of biostimulants for sustainable agriculture. Front. Plant Sci. 871:1473. doi: 10.3389/fpls.2018.01473

Bashan, Y. (1998). Inoculants of plant growth-promoting bacteria for use in agriculture. Biotechnol. Adv. 16, 729-770. doi: 10.1016/S0734-9750(98) 00003-2 and retain their ability to colonize the rhizosphere and achieve plant beneficial activity. Despite strain-specific differences, which need to be validated for each Pseudomonas strain of interest, both carriers yield similar results with no clear superiority of one over the other. The development of stable bioformulations is required for the commercialization of these organisms to be successfully used for plant growth promotion and/or biocontrol of plant pathogens in sustainable farming practices.

\section{DATA AVAILABILITY STATEMENT}

The original contributions presented in the study are included in the article/supplementary material, further inquiries can be directed to the corresponding author/s.

\section{AUTHOR CONTRIBUTIONS}

AN and MF contributed to the conception, design of the study, contributed to manuscript revision, read, and approved the submitted version. AN was responsible for conducting the experiments, the analyses, and writing the manuscript.

\section{FUNDING}

This study was funded by an Atlantic Innovation Fund grant to $\mathrm{MF}$.

\section{ACKNOWLEDGMENTS}

We acknowledge the Atlantic Innovation Fund grant to MF for supporting this study.

Bashan, Y., de-Bashan, L. E., Prabhu, S. R., and Hernandez, J. P. (2014) Advances in plant growth-promoting bacterial inoculant technology: formulations and practical perspectives (1998-2013). Plant Soil 378, 1-33. doi: 10.1007/s11104-013-1956-x

Basu, S., Rabara, R., and Negi, S. (2017). Towards a better greener future - an alternative strategy using biofertilizers. I: plant growth promoting bacteria. Plant Gene 12, 43-49. doi: 10.1016/j.plgene.2017.07.004

Berninger, T., González López, Ó., Bejarano, A., Preininger, C., and Sessitsch, A. (2018). Maintenance and assessment of cell viability in formulation of non-sporulating bacterial inoculants. Microb. Biotechnol. 11, 277-301. doi: $10.1111 / 1751-7915.12880$

Bettiol, W., Morandi, M. A. B., Pinto, Z. V., Paula Junior, T. J., Correa, E. B., Moura, A. B., et al. (2012). Produtos comerciais à base de agentes de biocontrole de doenças de plantas. Embrapa Meio Ambient. 88, 1-155.

Bhattacharyya, C., Bakshi, U., Mallick, I., Mukherji, S., Bera, B., and Ghosh, A. (2017). Genome-guided insights into the plant growth promotion capabilities of the physiologically versatile Bacillus aryabhattai strain AB211. Front. Microbiol. 8:411. doi: 10.3389/fmicb.2017.00411

Bhattacharyya, C., Roy, R., Tribedi, P., Ghosh, A., and Ghosh, A. (2020). "Biofertilizers as substitute to commercial agrochemicals," in Agrochemicals Detection, Treatment and Remediation Pesticides and Chemical Fertilizers, ed M. N. V. Prasad (Elseveier), 263-290.

Bishnoi, U. (2015). PGPR interaction: an ecofriendly approach promoting the sustainable agriculture system. Adv. Bot. Res. 75, 81-113. doi: 10.1016/bs.abr.2015.09.006

Compant, S., Samad, A., Faist, H., and Sessitsch, A. (2019). A review on the plant microbiome: Ecology, functions, and emerging trends in microbial application. J. Adv. Res. 19, 29-37. doi: 10.1016/j.jare.2019.03.004 
Compant, S., van Der Heijden, M. G. A., and Sessitsch, A. (2010). Climate change effects on beneficial plant-microorganism interactions. FEMS Microbiol. Ecol. 73, 197-214. doi: 10.1111/j.1574-6941.2010.00900.x

Corrêa, E. B., Sutton, J. C., and Bettiol, W. (2015). Formulation of Pseudomonas chlororaphis strains for improved shelf life. Biol. Control 80, 50-55. doi: 10.1016/j.biocontrol.2014.09.009

deCoste, N. J., Gadkar, V. J., and Filion, M. (2011). Relative and absolute quantitative real-time PCR-based quantifications of hcnC and phlD gene transcripts in natural soil spiked with Pseudomonas sp. strain LBUM300. Appl. Environ. Microbiol. 77, 41-47. doi: 10.1128/AEM.01 387-10

Dorigo, U., Lefranc, M., Leboulanger, C., Montuelle, B., and Humbert, J. (2009). Spatial heterogeneity of periphytic microbial communities in a small pesticide-polluted river. FEMS Microbiol. Ecol. 67, 491-501. doi: 10.1111/j.1574-6941.2008.00642.x

Dubey, K. K., and Kumar, P. (2018). "Microbes in crop improvement: future challenges and perspective," in Crop Improvement Through Microbial Biotechnology, eds R. Prasad, S. S. Gill, and N. Tuteja (Amsterdam: Elsevier), 415-425. doi: 10.1016/B978-0-444-63987-5.00021-9

Evans, J., Wallace, C., and Dobrowolski, N. (1993). Interaction of soil type and temperature on the survival of Rhizobium leguminosarum bv. viciae. Soil Biol. Biochem. 25, 1153-1160. doi: 10.1016/0038-0717(93)90209-T

Gade, R. M., Chaithanya, B. H., and Khurade, K. C. (2014). A comparitive study of different carriers for shelflife of Pseudomonas fluorescens. Biosacan. 9, 287-290.

Griffiths, R. I., Manefield, M., Whiteley, A. S., and Bailey, M. J. (2008). "DNA and RNA extraction from soil," in Molecular Microbial Ecology Manual, eds G. Kowalchuk, F. de Bruijn, I. Head, A. Akkermans, and J. van Elsas (Netherlands: Springer), 149-158.

Guijarro, B., Melgarejo, P., and De Cal, A. (2007). Effect of stabilizers on the shelf-life of Penicillium frequentans conidia and their efficacy as a biological agent against peach brown rot. Int. J. Food Microbiol. 113, 117-124. doi: 10.1016/j.ijfoodmicro.2006.06.024

Hassan, T. U., and Bano, A. (2015). Role of carrier-based biofertilizer in reclamation of saline soil and wheat growth. Arch. Agron. Soil Sci. 61, 1719-1731. doi: 10.1080/03650340.2015.1036045

Jambhulkar, P. P., and Sharma, P. (2013). Promotion of rice seedling growth characteristics by development and use of bioformulation of Pseudomonas fluorescens. Indian J. Agric. Sci. 83, 136-142.

Jiménez, J. A., Novinscak, A., and Filion, M. (2020). Pseudomonas fluorescens LBUM677 differentially increases plant biomass, total oil content and lipid composition in three oilseed crops. J. Appl. Microbiol. 128, 1119-1127. doi: $10.1111 /$ jam.14536

Jorjani, M., Heydari, A., Zamanizadeh, H. R., Rezaee, S., and Naraghi, L. (2011). Development of Pseudomonas fluorescens and Bacillus coagulans based bioformulations using organic and inorganic carriers and evaluation of their influence on growth parameters of sugar beet. J. Biopestic. 4, 180-185.

Khare, E., and Arora, N. K. (2015). "Effects of soil environment on field efficacy of microbial inoculants," in Plant Microbes Symbiosis: Applied Facets, ed. N. K. Arora (New Delhi: Springer), 353-381. doi: 10.1007/978-81-3222068-8_19

Khashei, S., Etemadifar, Z., and Rahmani, H. R. (2020). Multifunctional Biofertilizer from Pseudomonas putida PT : a potential approach for simultaneous improving maize growth and bioremediation of cadmiumpolluted soils. Sci. Inform. Database 8, 117-129.

King, E. O., Ward, M. K., and Raney, D. E. (1954). Two simple media for the demonstration of pyocyanin and fluorescin. J. Lab. Clin. Med. 44, 301-307.

Kumar, A., and Yadav, D. (2001). Long-term effects of fertilizers on the soil fertility and productivity of a rice-wheat system. J. Agron. Crop. Sci. 186, 47-54. doi: 10.1046/j.1439-037x.2001.00452.x

Lugtenberg, B., and Kamilova, F. (2009). Plant-growthpromoting rhizobacteria. Annu. Rev. Microbiol. 63, 541-556. doi: 10.1146/annurev.micro.62.081307.162918

Macik, M., Gryta, A., and Frac, M. (2020). Biofertilizers in agriculture: an overview on concepts, strategies and effects on soil microorganisms. Adv. Agron. 162, 31-87. doi: 10.1016/bs.agron.2020.02.001

Martínez-Viveros, O., Jorquera, M. A., Crowley, D. E., Gajardo, G., and Mora, M. L. (2010). Mechanisms and practical considerations involved in plant growth promotion by Rhizobacteria. J. Soil Sci. Plant Nutr. 10, 293-319. doi: 10.4067/S0718-95162010000100006

Mathre, D. E., Cook, R. J., and Callan, N. W. (1999). From discovery to use: traversing the world of commercializing biocontrol agents for plant disease control. Plant Dis. 83, 972-983. doi: 10.1094/PDIS.1999.83. 11.972

Mishra, J., and Arora, N. K. (2016). "Bioformulations for plant growth promotion and combating phytopathogens: a sustainable approach," in Bioformulations: for Sustainable Agriculture, eds N. K. Arora, S. Mehnaz, and R. Balestrini (New Delhi: Springer), 3-33. doi: 10.1007/978-81-322-2779-3_1

Moses, M., Johnson, E., Anger, W., Burse, V., Horstman, S., RJ, J., et al. (1993). Environmental equity and pesticide exposure. Toxicol. Heal. 9, 913-959. doi: 10.1177/074823379300900512

Nakkeeran, S., Kavitha, K., Mathiyazhagan, S., Fernando, W. G. D., Chandrasekar, G., and Renukadevi, P. (2004). Induced systemic resistance and plant growth promotion by Pseudomonas chlororaphis strain PA-23 and Bacillus subtilis strain CBE4 against rhizome rot of turmeric (Curcuma longa L.). Can. J. Plant Pathol. 26, 417-418. doi: 10.1094/PHYTO.2004.94.11.1259

National Research Council of Canada (1987). The Canadian Soil Classification System. Ottawa, ON: NRC Research Press, 187.

Novinscak, A., and Filion, M. (2018). Enhancing total lipid and stearidonic acid yields in Buglossoides arvensis through PGPR inoculation. J. Appl. Microbiol. 125, 203-215. doi: 10.1111/jam.13749

Novinscak, A., and Filion, M. (2019). Persistence of Pseudomonas fluorescens LBUM677 in the rhizosphere of corn gromwell (Buglossoides arvensis) under field conditions and its impact on seed oil and stearidonic acid bioaccumulation. J. Appl. Microbiol. 127, 208-218. doi: 10.1111/jam.14283

Paulitz, T. C., and Bélanger, R. R. (2001). Biological control in greenhouse systems. Annu. Rev. Phytopathol. 39, 103-133. doi: 10.1146/annurev.phyto.39.1.103

Pimentel, D. (1993). "Habitat factors in new pest invasions," in Evolution of Insect Pests-Patterns of Variation, eds K. Kim, and B. McPheron (New York, NY: Wiley), 165-181.

Podile, A. R., and Kishore, G. K. (2007). "Plant growth-promoting rhizobacteria," in Plant-Associated Bacteria, ed S. Gnanamanickam (Dordrecht: Springer), 195-230. doi: 10.1007/1-4020-4538-7_6

Raaijmakers, J. M., Paulitz, T. C., Steinberg, C., Alabouvette, C., and MoënneLoccoz, Y. (2009). The rhizosphere: a playground and battlefield for soilborne pathogens and beneficial microorganisms. Plant Soil 321, 341-361. doi: 10.1007/s11104-008-9568-6

Rabindran, R., and Vidhyasekaran, P. (1996). Development of a formulation of Pseudomonas fluorescens PfALR2 for management of rice sheath blight. Crop Prot. 15, 715-721. doi: 10.1016/S0261-2194(96)00045-2

Ramakrishna, W., Yadav, R., and Li, K. (2019). Plant growth promoting bacteria in agriculture: Two sides of a coin. Appl. Soil Ecol. 138, 10-18. doi: 10.1016/j.apsoil.2019.02.019

Reigart, J., and Roberts, J. (2013). Recognition and Management of Pesticide Poisonings. Washington, DC: Office of Pesticide Programs, U.S. Environmental Protection Agency, 272.

Rilling, J. I., Acuña, J. J., Nannipieri, P., Cassan, F., Maruyama, F., and Jorquera, M. A. (2019). Current opinion and perspectives on the methods for tracking and monitoring plant growth-promoting bacteria. Soil Biol. Biochem. 130, 205-219. doi: 10.1016/j.soilbio.2018.12.012

Schisler, D. A., Slininger, P. J., Behle, R. W., and Jackson, M. A. (2004). Formulation of Bacillus spp. for biological control of plant diseases. Phytopathology 94, 1267-1271. doi: 10.1094/PHYTO.2004.94.11.1267

Shaharoona, B., Jamro, G. M., Zahir, Z. A., Arshad, M., and Memon, K. S. (2007). Effectiveness of various Pseudomonas spp. and Burkholderia caryophylli containing ACC-deaminase for improving growth and yield of wheat (Triticum aestivum L.). J. Microbiol. Biotechnol. 17, 1300-1307.

Sobhan, A. S., Tayebi, L., Heydari, A., and Cheraghi, M. (2011). Evaluation of efficacy of new bioformulations on promotion of cotton seedlings growth characteristics. 2nd Int. Conf. Environ. Sci. Technol. 6, 361-364.

St-Onge, R., Gadkar, V. J., Arseneault, T., Goyer, C., and Filion, M. (2011). The ability of Pseudomonas sp. LBUM 223 to produce phenazine-1carboxylic acid affects the growth of Streptomyces scabies, the expression of thaxtomin biosynthesis genes and the biological control potential against common scab of potato. FEMS Microbiol. Ecol. 75, 173-183. doi: 10.1111/j.1574-6941.2010.00992.x 
St-Onge, R., Goyer, C., and Filion, M. (2010). Pseudomonas Spp. can inhibit streptomyces scabies growth and repress the expression of genes involved in pathogenesis. J. Bacteriol. Parasitol. 01, 1-6. doi: 10.4172/2155-9597.1000101

Tabassum, B., Khan, A., Tariq, M., Ramzan, M., Iqbal Khan, M. S., Shahid, N., et al. (2017). Bottlenecks in commercialisation and future prospects of PGPR. Appl. Soil Ecol. 121, 102-117. doi: 10.1016/j.apsoil.2017.09.030

Verma, P. P., Singla, H., Sharma, S., and Kaur, M. (2013). Evaluation of different carrier materials for preparation of fluorescent Pseudomonas formulation. Indian Phytopathol. 66, 107-108.

Vidhyasekaran, P., and Muthamilan, M. (1995). Development of formulations of Pseudomonas fluorescens for control of chickpea wilt. Plant Dis. 79, 782-786. doi: 10.1094/PD-79-0782

Vidhyasekaran, P., Sethuraman, K., Rajappan, K., and Vasumathi, K. (1997). Powder formulations of Pseudomonas fluorescens to control pigeonpea wilt. Biol. Control 8, 166-171. doi: 10.1006/bcon.199 7.0511

Viswanathan, R., and Samiyappan, R. (2008). Bio-formulation of fluorescent Pseudomonas spp. induces systemic resistance against red rot disease and enhances commercial sugar yield in sugarcane. Arch. Phytopathol. Plant Prot. 41, 377-388. doi: 10.1080/032354006007 96737
Yang, S. (2006). Effect of long-term feertilization on soil productivity and nitrate accumulation in Gansu oasis. Agric. Sci. China 5, 57-67. doi: 10.1016/S1671-2927(06)6 0020-5

Zayed, M. S. (2016). “Advances in formulation development technologies," in Microbial Inoculants in Sustainable Agricultural Productivity, eds. D. P. Singh, H. B. Singh, and R. Prabha (New Delhi: Springer), 219-237. doi: 10.1007/978-81-322-2644-4_14

Conflict of Interest: The authors declare that the research was conducted in the absence of any commercial or financial relationships that could be construed as a potential conflict of interest. A patent has been granted on $P$. fluorescens LBUM677 and its use to enhance total lipid and SDA yields in an oilseed crop (US patent $10,165,743$ ).

Copyright (C) 2020 Novinscak and Filion. This is an open-access article distributed under the terms of the Creative Commons Attribution License (CC BY). The use, distribution or reproduction in other forums is permitted, provided the original author(s) and the copyright owner(s) are credited and that the original publication in this journal is cited, in accordance with accepted academic practice. No use, distribution or reproduction is permitted which does not comply with these terms. 